\title{
ON NEOTROPICAL CARABIDAE (COLEOPTERA)
}

\author{
By Hans ReichardT*
}

In the course of the study of Neotropical Carabidae in the collections of the Museum of Comparative Zoology and the Departamento de Zoologia, a new species of Galeritula was recognized. It is described in order that the name will be available for use elsewhere. In addition new synonymies are established in some other genera of Neotropical Carabidae.

\section{Genus Otoglossa Chaudoir.}

Otoglossa Chaudoir, 1872, Ann. Soc. Ent. Belg., 15:158. Type: O. tuberculosa Chaudoir.

Heraldinium Liebke, 1927, Ent. Blaett., 23 : 101-102. Type: H. nevermanni Liebke. NEW SYNONYMY.

Liebke, 1938, Fest. Emb. Strand, $4: 42,88$.

Mateu, 1961, Ann. Mus. Civ. Stor. Nat. Genova, $72: 163,169$.

Liebke described Heraldinium as belonging to the Odacanthini, and included it in his Odacanthini revision of 1938. Studying a series of specimens that proved to be $O$. tuberculosa, I found (I) that this species has all characters of Heraldinium but (2) is different from nevermanni, the only species assigned to Heraldinium by Liebke. A more careful study brought me to the conclusion that Liebke's genus belongs to the Lebiini, and must be considered a synonym of Otoglossa. This genus, as defined recently by Mateu ( I96I), included only $O$. tuberculosa Chaudoir and subviolacea Mateu, to which nevermanni (Liebke) must now be added.

\section{Otoglossa tuberculosa Chaudoir}

(Figs. I-3)

Otoglossa tuberculosa Chaudoir, 1872, Ann. Soc. Ent. Belg., 15 :158-159. Type: Minas, Brazil; Paris Museum.

Mateu, 1961, Ann. Mus. Civ. Stor. Nat. Genova, 72:170. (see for additional references and synonyms).

To the localities given by Mateu, I add the following: from the Departamento de Zoologia: Ilha dos Buzios, São Paulo, I6.X.-4.XI. I963, Exp. Dep. Zool. col.; Caraguatatuba (Reserva Florestal, 40 m.), São Paulo, 22.V.r962, Exp. Dep. Zool. col.; Barueri, São Paulo, K. Lenko col.; Ponta Grossa, Paraná, III. I939, Camargo col.; from the Museum of Comparative Zoology: Nova Teutonia, Santa Catarina, F.Plaumann col.

*Departamento de Zoologia da Secretaria da Agricultura, São Paulo. On a fellowship of the Organization of American States at Harvard University. Manuscript received by the editor March 6, 1964. 

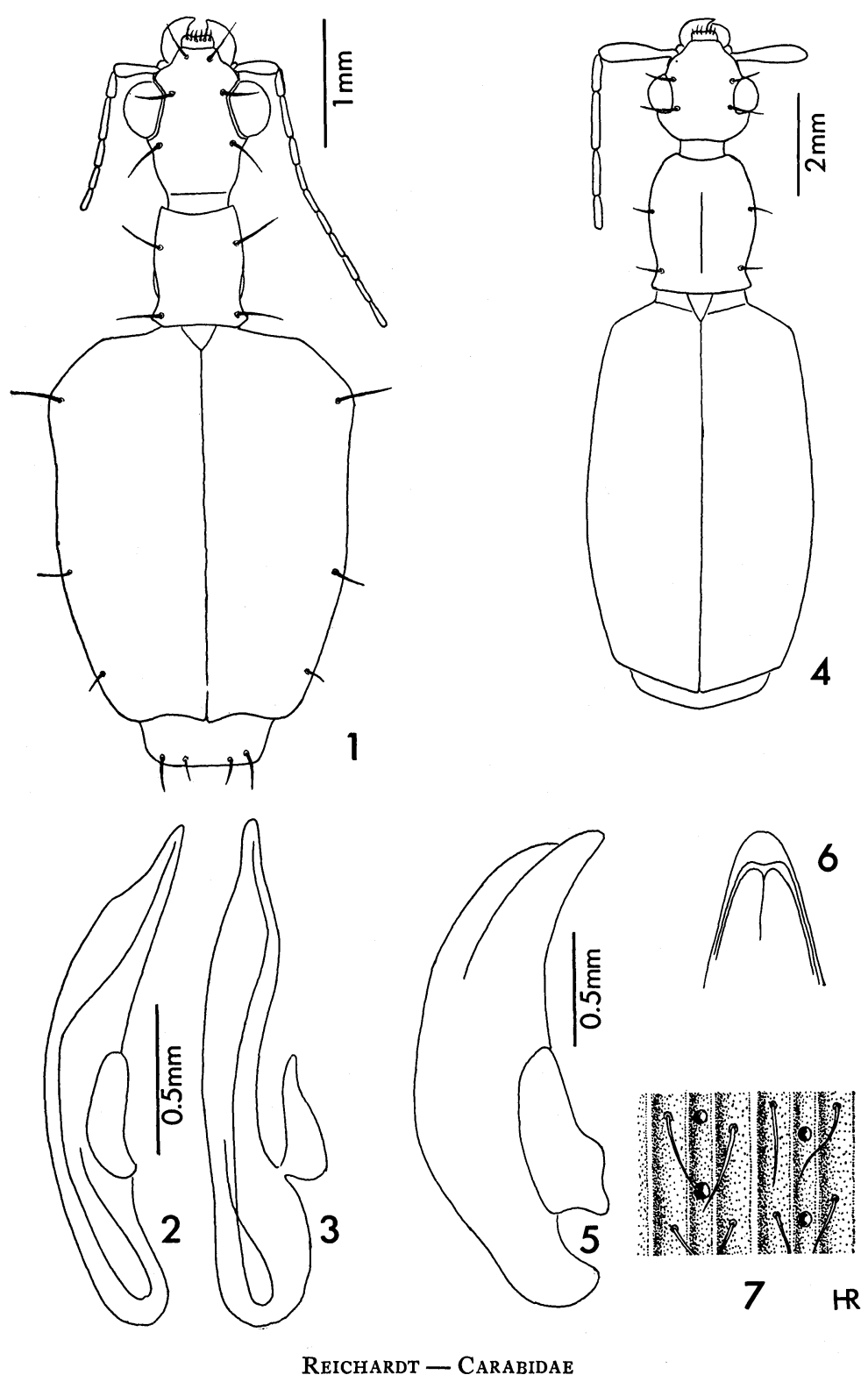


\section{Galeritula pilosa, n. sp.}

(Figs. 4-7)

Description: dark brown, almost black, with lighter brown legs, antennae and mouthparts. Winged species.

Head slightly wider than long, with large prominent eyes; slightly rugose, with broad, poorly developed median carina; posterior half and sides of anterior half with long yellowish, almost erect hairs; two orbital setae. Pronotum longer than wide (length to width ratio: I.2); as wide as head; anterior margin concave, posterior margin slightly emarginate; widest in the middle; more narrowed anteriorly; sides divergent after the constriction; surface convex, rugose; median sulcus almost erased; covered with long yellowish, backwards directed hairs; two pronotal setae. Scutellum triangular, punctured, with yellow hairs. Elytra twice as wide as pronotum, almost twice as long as wide (length to width ratio: 1.8 ) ; widest behind the middle; apex truncate; with nine carinae and two less developed carinulae between each two carinae; a row of deep punctures filling out the carinulae interspace; a row of long yellow hairs (more or less as long as interspace between two carinae) between each carina and carinula; interspaces transversely rugose; scutellar carina usually not joining the first carina (in the holotype the right one joins it). Legs (the holotype has the right middle femur bifurcated at apex), antennae, mouthparts and ventral side, very densely hairy.

Measurements: length $12.6 \mathrm{I}-14.56 \mathrm{~mm}$; width $4.16-4.8 \mathrm{I} \mathrm{mm}$. (Holotype: $13 \mathrm{~mm}$. $\times 4.16 \mathrm{~mm}$.).

Types: Salobra, Mato Grosso, X. I938, Exp. Instituto Oswaldo Cruz col. (Holotype $0^{\circ}$ and $40^{\circ}$, 6o, Paratypes; io, Paratype, same locality, I.1955, no collector; all in the Departamento de Zoologia, São Paulo; I $0^{*}$ and Io, Paratypes, same data as Holotype, in the Museum of Comparative Zoology, Cambridge, Mass.

Notes: this species of Galeritula is well defined by its rather small size, and by the long yellowish hairs which cover it. Very similar to G. palustris (Liebke), of which $20^{\pi}$ and 39 were collected together with pilosa, n. sp.; distinguished by its darker brown legs; by the different pronotal form; by the carinae, which are thicker than in palustris, and by the pilosity, which is much denser and longer in pilosa, n. sp.

\section{Explanation of Plate 7}

Otoglossa tuberculosa Chaudoir: fig. 1, dorsal view; fig. 2, genitalia of $\hat{\sigma}$ from Nova Teutonia, lateral view; fig. 3, same genitalia, dorsal view; Galeritula pilosa, n. sp.: fig. 4, Holotype; fig. 5, lateral view of genitalia of Holotype; fig. 6, same genitalia, dorsal view ; fig. 7, detail of elytral structure. 
Trichognathus marginipennis Latreille

Trichognathus marginipennis Latreille, 1829, Regne Anim., 2. ed., 4:375. Type: Brazil.

Trichognathus cinctus Chaudoir, 1848, Bull. Soc. Nat. Mosc., 21(1) :68. Type: Colombia. NEW SYNONYMY.

Trichognathus immarginipennis Steinheil, 1875, Col. Hefte, 13:96. Type: Muzo, Colombia. NEW SYNONYMY.

Having seen abundant material showing all possible grades of variation between typical specimens of the three described species, I consider these species as synonyms. Van Emden (I935, Rev. Ent., 5:3 I4), pointed out that the great variation in these species, made it almost impossible to separate them, when larger series were studied. Liebke ( 195 I, Beitr. Faun. Perus, 2:260) comes to almost the same conclusion, although he observes a geographic variation in the yellow elytral border. I cannot find geographic variation in this or any other character. In a series of specimens from Nova Teutonia, Santa Catarina, I found specimens which could be assigned to "cinctus" and to "marginipennis", together with intermediate specimens; in another series from Dept. del Cuzco, Peru, all three "species" were represented; not only "cinctus" in Peru and "marginipennis" in Southern Brazil, as supposed by Liebke.

There is a fourth species of Trichognathus listed in the catalogues: strangulatus Lacordaire, which must be eliminated from this genus, since it was designated as type species of another genus (Ancistroglossus) by Chaudoir [1862, Bull. Soc. Nat. Mosc., 35 (4):307]. 

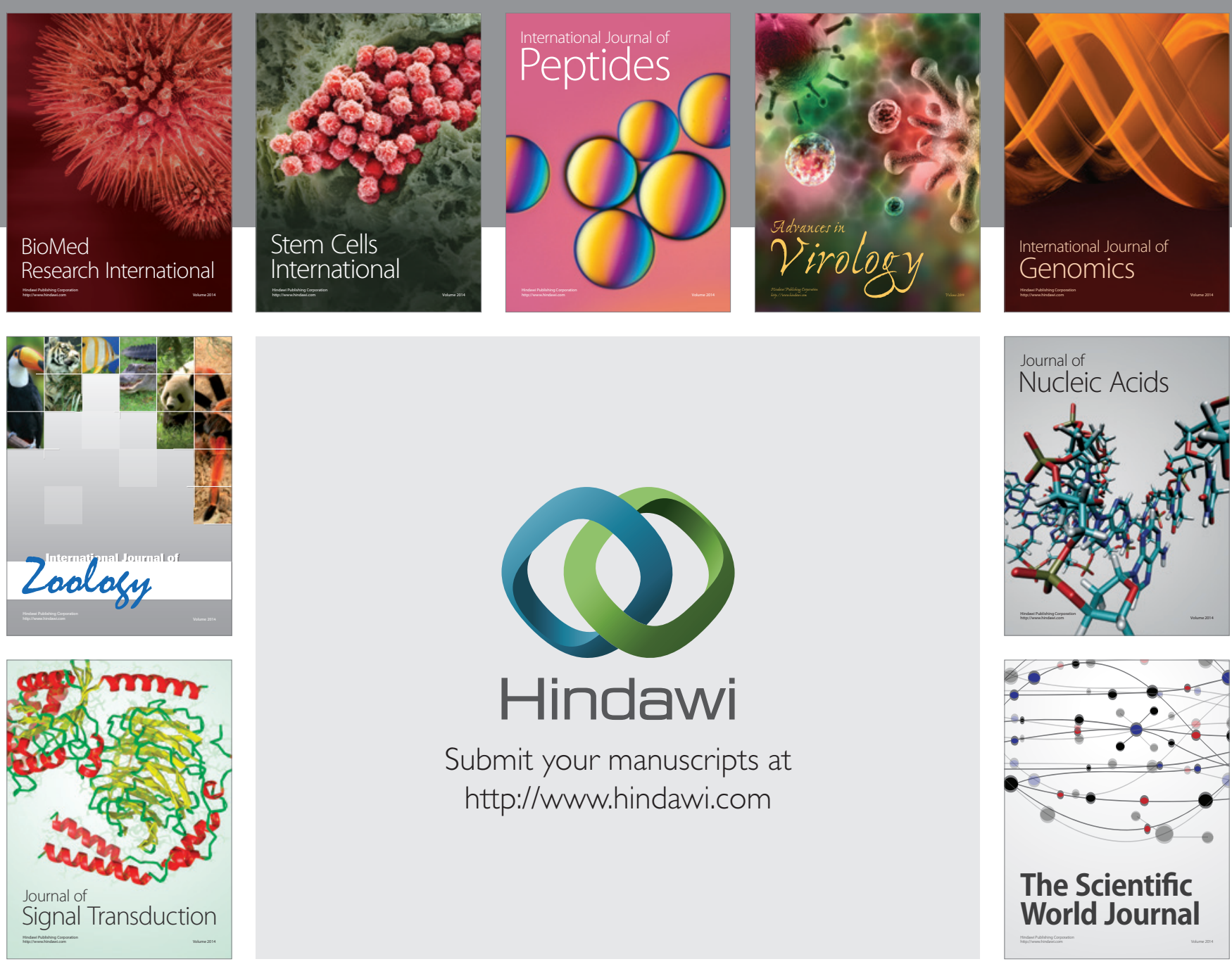

Submit your manuscripts at

http://www.hindawi.com
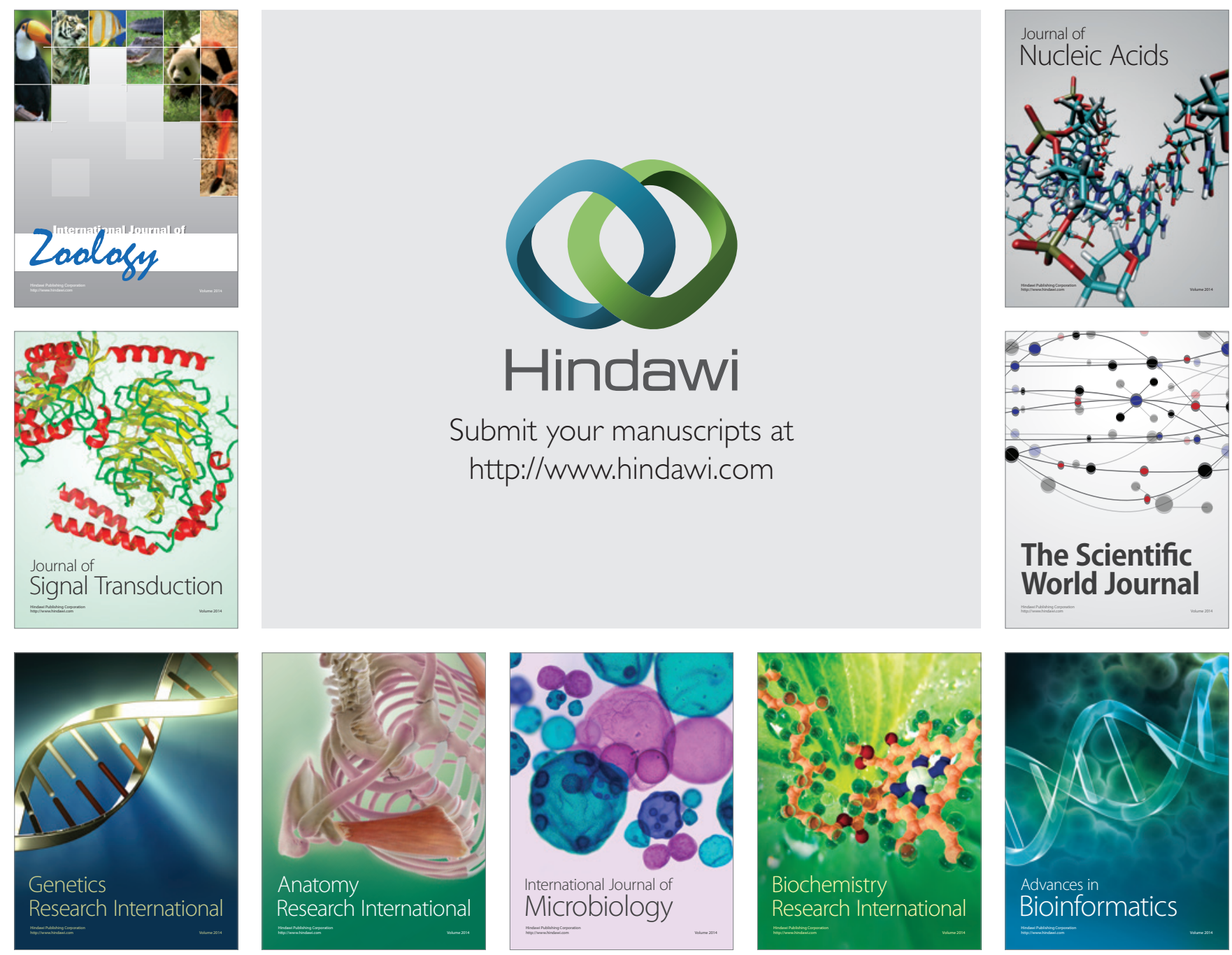

The Scientific World Journal
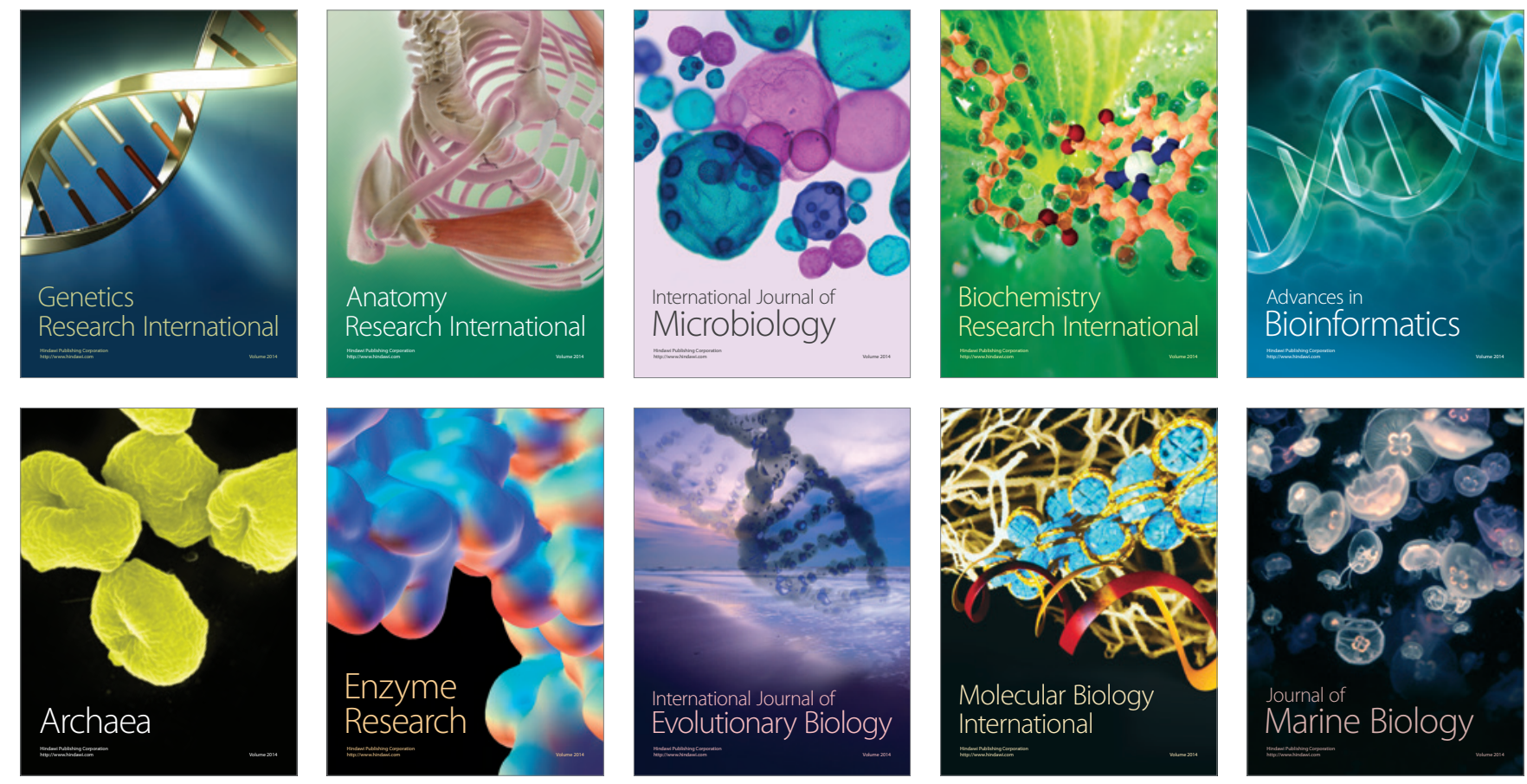